\title{
Predestinasi
}

Volume 14, No. 1, Juni 2020, Hal. 35- 40

ISSN (Print): 1978-9351

\section{Pentecostalism and Development: The Role and Prospects of Prosperity Gospel in the Socio-Economic Development of Nigeria}

\author{
Offiong Offiong Asuquo \\ Department of Religious \& Cultural Studies, University of Calabar, Calabar, Nigeria \\ *e-mail: offiongasuquo@unical.edu.ng
}

\begin{abstract}
The prosperity gospel is a popular doctrine that is taught and practised by many Pentecostal churches in Nigeria. It has enhanced and improved the financial status of many Pentecostal churches thereby enabling them to carry out several projects which have enhanced the socioeconomic wellbeing of many people. Such projects include the establishment of schools, universities, printing presses, financial empowerment of members, provision of welfare packages and care for the needy. This paper highlights the meanings of Pentecostalism, prosperity gospel and development. It also attempts to explain how prosperity gospel, in the context of some Pentecostal churches- Living Faith Church (Winners Chapel) and Christian Central Chapel International, among others, have contributed to the socio-economic wellbeing of many. However, this paper acknowledges that there is room for an improvement and expansion of the contributions of prosperity gospel to development in the future. Hence suggestions are given on how to harness, improve and expand the benefits of the prosperity gospel in Nigerian society in the future.
\end{abstract}

Keywords: Pentecostalism; Development; Nigeria; Prosperity Gospel.

\section{INTRODUCTION}

Pentecostal groups are very popular today. Global Pentecostalism and Charismatic Christianity, in all their diversity, are the fastest expanding religious movements in the world today (Miller \& Onyinah 2013). Pentecostals expanded through the late 20th century to at least 380 million, by the most conservative estimate, put forth by John L. Allen Jr. In Christian terms, the late 20th century will probably come to be known as the era of the "Pentecostal Explosion." From less than six percent in the mid-1970s, Pentecostals finished the century representing almost 20 percent of world Christianity, according to a 2006 study by the Pew Forum on Religion and Public Life called Spirit and Power. "Certain studies forecast a growth of 2.25 percent in Pentecostal population in comparison with the 1.23 percent increase in the world population in the past century" (Cartledge 2018). Pentecostalism's growing numbers strongly indicate that the movement will be a major force in shaping the religious landscape of the 21st century. Pentecostalism has become globalized, having many ecumenical implications; and its adherents are often on the cutting edge of the encounter with people of other faiths (Alamu 2019). In direct and indirect ways, Pentecostal beliefs and practices are remaking the face of world Christianity (Edet 2007; Edet 2011). 
They keep on expanding daily and do exert a great impact on Nigerian Society. Their influence, attractiveness and growth depend greatly on the concept of the prosperity gospel and in turn, some of them have contributed to the socio-economic development of Nigeria. This paper examines the role of prosperity gospel through some Pentecostal churches in the socio-economic development of Nigeria and also looks at the prospects and possibilities it holds for the future.

\section{DEFINITION OF KEY TERMS:}

\section{Pentecostalism}

The words Pentecostal or Pentecostalism are derived from the Greek Word "Pentecostos" which means fifty. Pentecost is the name given to the Feasts of Weeks which was celebrated annually by the Jews on the fiftieth day after the waving of the sheaf of the first-fruits before the Lord (Harris 2019). It is called the feast of the harvest because on this day the first fruits of the wheat harvest were offered to the Lord. It is also called "Pentecost" because it began exactly fifty days from the Passover (Fawole 1980). The baptism or coming of the Holy Spirit occurred on a Pentecost day according to Acts 2:1-4, hence, the word "Pentecost" became associated with the coming and manifestations of the Holy Spirit such as speaking in tongues, miracles and seeing visions. Hence, the belief and practise of these is described as Pentecostalism, and the practitioners are called Pentecostals.

\section{Prosperity Gospel}

Prosperity Gospel is the Christian religious belief and doctrine which holds that God provides for those he favours. It states that believers have a right to the blessings by sowing seeds through the faithful payment of tithes and offerings. Urquhart states that God causes his children to prosper when they live by the principles of the kingdom and exercise their faith in God's goodness. Giving is the secret of receiving (Idahosa 1987; Edet 2009). It also means that God's abundant goodness will be enjoyed by those who discipline themselves, become decisive, bold, advantageous, believing, daring, risking and determined (Idahosa 1987).

The prosperity gospel is the teaching that believers have a right to the blessings of health and wealth and that they can obtain these blessings through positive confessions of faith and the sowing of seeds through the faithful payments of tithes and offerings (Stambaugh 2020). In summary, the prosperity gospel holds that God has provided all the needs of those who worship and serve him. Thus they are encouraged to receive them by faith, service, sacrifices and offerings to God.

\section{Development}

Development has many definitions and meanings and there is no universally accepted definition. Rodney (1972) states that at the individual level, it implies increased skill and capacity, greater freedom, creativity, self-discipline, responsibility and material well-being, the achievement of any of these aspects of personal development is very much tied in with the state of the society. Here development is seen as an improvement, well-being and progress of the people. 
Development also means the following: investing in people through education, health, nutrition and family planning, creating the right climate for an enterprise by ensuring competitive markets, removing market rigidities, clarifying legal structures and providing infrastructure, fastening integration with the global economy through promotion of open trade and capital flows, and ensuring macro-economic stability (Steer and Anderson 1972; Houlden 1979).

Iwe (1979) throws more light on development by stating the features of development as follows (a) the existence of social security(b) the practise of responsible and generous family planning (c) improved mechanization and modernization of agriculture and functional economic sector (d) the articulation and adoption of a national ideology as a basis for effective inculcation of social values for the political education of the people (e) the encouragement of the development of science and technology (f) the provision of a viable population policy based on accurate data for effective socio-economic planning purposes $(\mathrm{g})$ the provision of accurate employment $(\mathrm{h})$ the provision of a constitution that guarantees fairness, equality and human rights (185-187).

In summary, development implies progress, improvements, changes and general wellbeing. It enhances the welfare of the people in all ramifications.

\section{THE POSITION OF PROSPERITY GOSPEL IN PENTECOSTAL CHURCHES IN NIGERIA}

To establish the link between prosperity gospel and development, it is necessary to highlight its context and manner of operation. The prosperity gospel is widely preached by many Pentecostal churches although some do emphasize it more than others. Primarily, the teaching and beliefs of the Pentecostals involve the following issues - sin, repentance, salvation, born again, sanctification, baptism in the holy spirit and speaking in tongues, the devil and demonology and the second coming of Christ and eternal life with him (Offiong 2003; Offiong 2018; Offiong 2019).

However, nowadays, these teachings have received less emphasis and they rather emphasize prosperity gospel and the acquisition of wealth for the present life (Offiong 2003). This makes the teaching, practise and application of the prosperity gospel to be a regular and essential aspect of the operations of the Pentecostal churches. This results in the regular giving of tithes, offerings and sowing of seeds in most meetings of the churches. The prosperity gospel is the basis, engine or catalyst which makes people always give to the various churches that emphasize it. Offerings also include vows and donations. Vows involve a situation in which an individual requests a favour from God and promises to thank Him with some gifts, money and testimonies if that favour is granted (Offiong 2003). Donations are contributions made for specific projects in the church, members are encouraged to give or pledge a reasonable amount for projects.

The sowing of seeds involves encouraging members to give offerings or donations as a means of getting back a hundredfold. This expectation of getting back a return in proportion to what one sow encourages people to give or sow larger offerings. The giving of a tithe is common in Pentecostal churches. A tithe is one-tenth of a Christian's income, which is to be paid to the church mandatorily. It is traced to the Bible in Genesis 14:18-20, where Abraham paid one-tenth of his possession to Melchizedek the high priest (Orogwu 1990). This is further supported in Numbers 18:21 which says "I give to the Levites all the tithes in Israel as their inheritance in return for the work they do while serving at the tent of meeting'. All the various types of donations, offerings and tithes are meant to support ministerial work and ministers. They bring 
blessings, favour and prosperity to those who give. These offerings and donations also strengthen the churches financially and enable them to contribute to the socio-economic welfare and development of the society through various projects.

The next section will examine some contributions of some prosperity gospel-centered Pentecostal churches to the socio-economic development of Nigeria.

\section{THE ROLE OF PROSPERITY GOSPEL IN THE SOCIO-ECONOMIC DEVELOPMENT OF NIGERIA}

The role of the prosperity gospel in the socio-economic development of Nigeria could be properly understood from the perspective of how it has enriched and enabled some Pentecostal churches to fulfill this role. It is like the fire, spirit, or engine that ignites, fires, or drives the churches to carry out useful projects in society. The contributions of two churches are going to be considered, namely the Living Faith church (AKA Winners Chapel), and the Christian Central Chapel (AKA. City of Testimonies).

The Living Faith Church has enhanced the socio-economic development of the society in the following ways:

1. Award of scholarship and bursaries to needy students at various levels

2. Provision of employment to many in the church's schools, colleges and universities.

3. There is a regular practise of donating clothes, food, money for the less privileged within and outside the church.

4. The church organizes business workshops and pieces of training to develop members and improve their economic well-being.

5. The church finances small scale businesses through the provision of small scale loans

6. The church has a welfare department that cares for and promotes the welfare of members and non-members.

7. The church regularly embarks on visitations and outreaches to orphanages, prisons and hospitals. Such visitations involve donations, counseling, prayers and other spiritual ministrations.

8. The church plays an effective role in recommending its members for job appointments or other posts as referees, guarantors or trustees, thereby enhancing their economic advancements.

In addition to the above, the church has established two universities namely Covenant University at Otta and Landmark University in Kwara state. They have also established schools at all state's headquarters of the church. These are comprised of the nursery, primary and secondary schools, and they are called Kingdom Heritage Schools. They all provide education, training and skills which enable many to improve their economic and social well-being. Furthermore, the church has established Dominion Publications, which is a publishing company that renders commercial services and provides employment to many.

Secondly, the Christian Central Chapel International (AKA City of Testimonies) has also contributed in similar ways to the socio-economic development of the society.

1. They have a welfare department that cares for the needy members and non-members. Special welfare days are held monthly to support the poor.

2. The church also embarks on visitations to orphanages, prison yards, widows and other poor people, to support them. 
3. The church empowers youths economically, enables them to acquire skills through training, grants, loans, recommends members for jobs and introduces and exposes members to job opportunities.

These contributions to the socio-economic development of the people apply to other prosperity based Pentecostal churches. Some of them are Christ Embassy Church, Redeemed Christian Church, Christ Diplomats Church and several others.

Their efforts are enhanced by the preaching of prosperity gospel which ensures the availability of enough funds to support the projects. Thus, the prosperity gospel has contributed greatly to the socio-economic development of many people through these churches. To maintain and improve on this role of the prosperity gospel, there is a need to suggest and highlight the way this could be achieved. This comes under the prospects.

\section{THE PROSPECTS OF PROSPERITY GOSPEL IN THE SOCIO-ECONOMIC DEVELOPMENT OF NIGERIA}

Given the role of the prosperity gospel in socio-economic development, all churches should emulate the steps of the Pentecostal churches in ensuring the welfare of people. This will greatly improve society on a large scale. The adoption and practise of the seven pillars of prosperity gospel as propagated by Oyedepo (1997) will greatly improve the socio-economic life of the people. The pillars are: giving, honest labour, wise planning, trusting, waiting, positive confession, and thanking God. The persuasive and convincing abilities of the prosperity preachers could also be used to mobilize people towards other positive goals and virtues such as loyalty, patriotism, love, and peaceful existence. Churches should be properly guided to invest part of their revenue in the socio-economic development of the people. These include education, healthcare, special care centres, and business financing.

\section{CONCLUSION}

This paper has established that the prosperity gospel has contributed through the Pentecostal churches to the socio-economic development of the people. This is done by improving the churches financially and enabling them to carry out various projects and to support many people. However, there is room for improvement, expansion and sustenance of the role of the prosperity gospel in the socio-economic development of people. Some suggestions have been given under the previous section, if they are implemented, they will greatly improve the role of the prosperity gospel in the socio-economic development of Nigeria.

\section{REFERENCES}

Alamu, A. G. (2019). "Putting old wine in new wine skins": The place of African indigenous churches in the Nigerian Pentecostals. In African Renaissance (Vol. 16, Issue 2, pp. 165185).

Asuquo, O. O. (2018). The Role of the African Church Movement in Nigeria's Independence. GNOSI: An Interdisciplinary Journal of Human Theory and Praxis, 1(1), 48-52.

Asuquo, O. O. (2019). The Social Significance and Implications of the Ekpe Shrine In Calabar. GNOSI: An Interdisciplinary Journal of Human Theory and Praxis, 1(2). 
40 Predestinasi

Volume 14, No. 1, Juni 2020 Hal. 35- 40

Cartledge, M. J. (2018). Pentecostal theology: living the full gospel. Journal of the European Pentecostal Theological Association, 38(2), 185-186. https://doi.org/10.1080/18124461.2018.1456108

Edet, F. F. (2007). Jesus in Africa. Sophia: An African Journal of Philosophy, 10(1), 156-163.

Edet, F. F. (2009). The concept of God in African traditional religion. Sophia: An African Journal of Philosophy, 12(1), 127-135.

Edet, F. F. (2011). The contribution of religion to national development: A case study of living Faith church aka Winner Chapel. Sophia, 10 (2), 91-97

Fawole, L. S. (1980). Essentials of Bible Knowledge Ibadan Daystar.

Harris, A. L. (2019). Black Pentecostal Hermeneutics? James H. Cone's theological sources and black pentecostalism. Pneuma, 41(2), 193-217. https://doi.org/10.1163/1570074704102004

Harris, A. L. (2019). Black Pentecostal Hermeneutics? Pneuma, 41(2), 193-217. https://doi.org/10.1163/15700747-04102004

Houlden, J. L. (1979). The Development of Meaning. Theology, 82(688), 251-259. https://doi.org/10.1177/0040571X7908200403

Idahosa, B. (1987). I choose to change- Crowborough: Highland.

Inyang, M. J. P., Alegu, J. C., \& Maku, B. S. (2020). Development Communication Process and Theories: An Overview. GNOSI: An Interdisciplinary Journal of Human Theory and Praxis, 3(1), 61-75.

Iwe, N.S. (1979). Christianity, Culture and Colonialism in Africa Calabar: Saesprint.

Miller, L., \& Onyinah, O. (2013). The Movement of the Spirit Around the World in Pentecostalism. Transformation: An International Journal of Holistic Mission Studies, 30(4), 273-286. https://doi.org/10.1177/0265378813503234

Obilor, O. I., Kenneth, I., Okoroafor, F. O., Chima, E., \& Bello, M. B. (2018). Democracy and National Development: A Focus on Nigeria.

Offiong E.A. (2003) Pentecostalism in Nigeria, Calabar Experience, 1970-1995. Calabar: Glad Tidings.

Orogwu, J. N. (1990). Tithe Yourself out of Poverty: With notes on giving Enugu: Atlantic Publishers.

Oyedepo, D.O. (1997). Understanding Financial Prosperity Lagos: Dominion.

Rodney, W. (1972). How Europe Underdeveloped Africa: Tanzania Publishing House.

Stambaugh, J. R. (2020). Pentecostalism as a Christian Mystical Tradition. Anglican Theological Review, 102(2), 316.

Steer, A., et al. (1972). Development and the Environment. Oxford! Oxford U.P. 